\title{
PENGARUH PENAMBAHAN TEPUNG KACANG HIJAU TERHADAP KARAKTERISTIK BOLU KUKUS BERBAHAN DASAR TEPUNG UBI KAYU (Manihot esculenta)
}

\author{
Sahri Yanti ${ }^{1}$, Nur Wahyuni ${ }^{2}$, Heru Pitria Hastuti ${ }^{3}$ \\ Fakultas Teknologi Pertanian Universitas Teknologi Sumbawa \\ ${ }^{*}$ Corresponding Author email: sahri.yanti@uts.ac.id
}

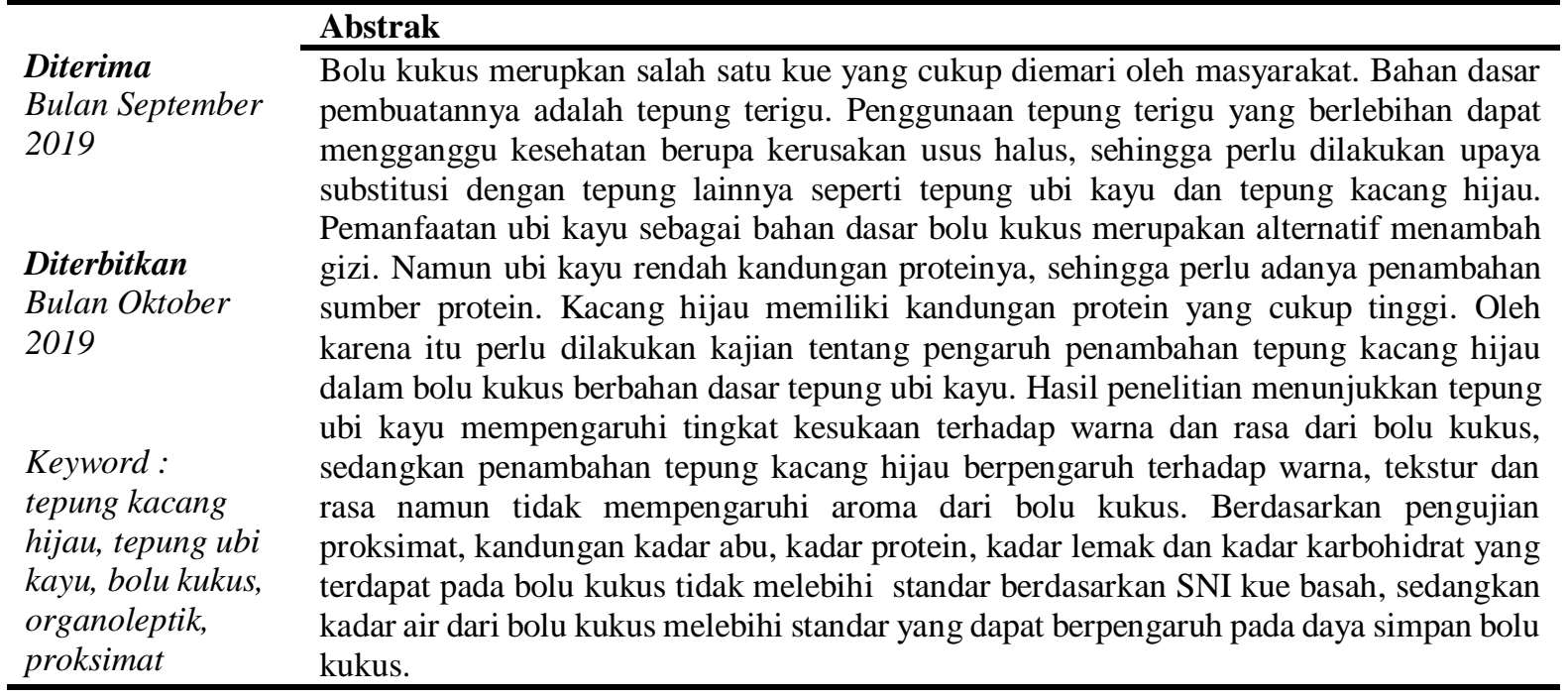

\section{PENDAHULUAN}

Bolu kukus adalah salah satu makanan yang berbahan dasar tepung terigu. Tepung terigu dapat membuat adonan mengembang, karena mengandung gluten. Gluten adalah protein yang terkandung dalam tepung yang dibuat dari serealia termasuk gandum. Gluten membuat adonan kenyal dan dapat mengembang karena bersifat kedap udara. Bila terkena bahan cair maka gluten akan mengembang dan saling mengikat dengan kuat membentuk adonan yang sifatnya liat. (Anshari, 2010)

Penggunaan tepung terigu yang berlebihan dapat mengganggu kesehatan yaitu kerusakan usus halus. Kerusakan usus halus menyebabkan gangguan penyerapan zat gizi yang masuk ke dalam tubuh (Kadarwati, 2015). Kandungan gluten pada tepung terigu juga tidak baik untuk penderita autis. Tepung terigu juga memiliki kandungan glikemik yang tinggi sebesar 70. Konsumsi makanan yang mengandung glikemik tinggi akan meningkatkan kadar gula darah sehingga tidak baik untuk penderita diabetes mellitus (Muchtadi dalam Kadarwati, 2015). Oleh karena itu, konsumsi dari tepung terigu harus dikurangi agar tidak berdampak buruk bagi kesehatan. Dalam penelitian ini, penggunaan tepung terigu sebagai bahan baku akan disubstitusi dengan tepung ubi kayu dan tepung kacang hijau.

Pemanfaatan ubi kayu sebagai bahan dasar bolu kukus merupakan suatu alternatif menambah gizi yang baik. Diketahui bahwa kandungan gizi terbesar dari ubi kayu adalah karbohidrat $34 \mathrm{~g}$, protein $1,20 \mathrm{~g}$, lemak $0,30 \mathrm{~g}$, vitamin C $30 \mathrm{mg}$, kalori 121 kal (Dewi, 2011). Tepung ubi kayu dapat digunakan untuk mengganti tepung gandum dan baik untuk pengidap alergi (FAO, 2013). Tepung ubi kayu mengandung pati $83,8 \%$, lemak $0,9 \%$, protein $1 \%$, serat $2,1 \%$, abu $0,7 \%$. Kekurangan dari ubi kayu adalah rendahnya kandungan protein, sehingga untuk meningkatkan kandungan protein produk olahan yang dihasilkan dari tepung ubi kayu perlu adanya penambahan sumber protein, misalnya dari tepung kacang-kacangan (Suharno, 1990).

Kacang-kacangan merupakan salah satu sumber protein nabati yang baik untuk dikonsumsi. Salah satu dari jenis kacang-kacangan tersebut adalah kacang hijau. Kacang hijau memiliki kandungan protein yang cukup tinggi yaitu sebesar $22,9 \%$ dan merupakan sumber mineral yang penting antara lain kalsium dan fosfor. Kacang hijau memiliki kandungan gizi yang lumayan tinggi dibandingkan dengan jenis kacang-kacangan lainnya (Purwanti, 2008). Penggunaan tepung ubi kayu dan tepung kacang hijau sebagai campuran pada pembuatan produk pangan di Indonesia belum banyak dilakukan. Untuk meningkatkan kegunaan tepung ubi kayu dan kacang hijau sebagai sumber pangan, dilakukan pengolahan tepung ubi kayu dan tepung kacang hijau menjadi bolu kukus yang pada umumnya berbahan baku tepung terigu. Oleh karena itu, pada penelitian ini akan menggunakan tepung ubi kayu dan tepung kacang hijau sebagai formulasi 
pembuatan bolu kukus, sehingga menghasilkan bolu kukus yang dapat diterima masyarakat dengan kualitas baik dan memiliki kandungan gizi yang cukup tinggi. Berdasarkan hal tersebut, perlu dilakukan penelitian untuk mengetahui pengaruh "Pengaruh Penambahan Tepung Kacang Hijau Terhadap Karakteristik Bolu Kukus Berbahan Dasar Tepung Ubi Kayu (Manihot esculenta)". Penelitian bertujuan mengetahui proses pembuatan tepung kacang hijau, proses pembuatan bolu kukus, pengaruh tepung kacang hijau terhadap karakteristik bolu kukus, kualitas bolu kukus berbahan dasar tepung ubi kayu.

\section{LANDASAN TEORI}

\section{Kacang Hijau}

Manfaat kacang hijau bagi kesehatan manusia yaitu: peluruh air seni, melawan disentri, melenyapkan biang keringat, menghilangkan bisul, menyuburkan rambut, menguatkan imunitas tubuh, menyehatkan tulang, menurunkan kolesterol, melancarkan pencernaan, mengurangi resiko kanker, sumber protein nabati, mengendalikan berat badan, mengurangi resiko anemia, mencegah tekanan darah tinggi, menyehatkan otak, keluhan pascamenopause, diabetes, mencegah penyakit jantung dan bermanfaat bagi ibu hamil dan menyusui (Mustakim, 2012)

Tepung kacang hijau termasuk kategori tepung yang berasal dari biji-bijian (grains) dan merupakan bahan yang bebas dari gluten (Dahlia, 2014). Tepung kacang hijau sangat bergizi untuk pertumbuhan. Pengolahan kacang hijau sangat bervariatif mulai dari makanan ataupun minuman, bahkan dapat digunakan sebagai obat-obatan. Hal ini dikarenakan tepung kacang hijau mengandung gizi, antara lain protein, lemak dan asam amino. Proses pembuatan tepung kacang hijau sebagai berikut: cuci kacang hijau hingga bersih, kemudian rendam dalam baskom atau bak yang berisi air bersih selama 24 jam dengan jumlah air 4 kali jumlah kacang hijau. Buang air rendaman lalu cuci kacang hijau tersebut. Lepaskan kulit dari bijinya, kemudian giling sampai halus, setelah itu saring dengan kain kasa. Endapkan selama 8 - 12 jam, kemudian buang air endapan yang berwarna hijau kekuningan. Bersihkan sampai jernih. Jemur endapan tersebut sampai kering (biasanya memakan waktu 3 hari jika panas normal). Tepung yang sudah kering siap untuk digunakan atau dikemas (Mustakim, 2012).

\section{Tepung Ubi Kayu}

Tepung ubi kayu adalah tepung yang dibuat secara langsung dari ubi kayu yang dikeringkan dan dijadikan tepung, tapi bukan dibuat gaplek sehingga warnanya masih keputihan. Sementara tepung gaplek berwarna kekuningan, sedikit cokelat dan memiliki bau yang berbeda.
Sekarang ini telah banyak berkembang industri kecil yang memproduksi tepung ubi kayu. Tepungnya sendiri bisa dibuat menjadi mie singkong dan hasil masakan yang lezat, bergantung pada bagaimana mengolah resep dan campuran isinya (Sindo, 2012)

Proses pembuatan tepung ubi kayu dapat dilakukan dengan beberapa cara, salah satunya yaitu melalui proses pengupasan, perendaman, pemarutan, pengepresan, kemudian dikeringkan sehingga menjadi tepung ubi kayu. Proses pembuatan tepung ubi kayu secara tradisional diawali dengan pengupasan dan pencucian sampai penggilingan, pengeringan dan pengayakan. Pengolahan ubi kayu dengan cara tradisional dalam proses pembuatan tepung, lebih praktis dan hemat biaya untuk penyajian tepung ubi kayu (Amin, 2006). Dengan cara baru, proses pembuatan tepung ubi kayu dilakukan melalui tahap pengeringan dengan alat pengering (kabinet), proses pengeringan lebih cepat dan mengurangi tingkat kerusakan pada tepung yang dihasilkan. Proses fermentasi yang dilanjutkan dengan proses pengeringan dapat membantu dalam penurunan atau penghapusan senyawa-senyawa beracun.

\section{Bolu Kukus}

Bolu kukus merupakan produk kue yang terbuat dari terigu, gula, lemak dan telur. Pembuatan bolu kukus membutuhkan pengembangan gluten dan biasanya digunakan bahan pengembang serta dibutuhkan pembentuk emulsi (kompleks air dalam minyak) dimana lapisan air terdiri dari gula terlarut dan partikel tepung terlarut. Perbedaan yang paling utama antara bolu kukus dengan produk kue lain adalah pada tekstur adonan, adonan bolu kukus bertekstur kental (Sunaryo, 1985).

Pada umumnya bolu dimatangkan dengan 2 cara, dipanggang di dalam oven dan dikukus. Faktor keberhasilan dalam pembuatan bolu kukus adalah dalam cara mengocok adonan dan mengukus adonan, misalnya mengocoknya terlalu lama atau terlalu sebentar ataupun pengukusannya tidak sempurna bisa membuat bolu kukus tidak jadi (Rohimah, 2008). Bahan dasar untuk pembuatan bolu kukus dibagi dalam 2 jenis. Pertama jenis bahan yang membentuk dasar bolu kukus adalah tepung, telur dan susu. Kedua adalah jenis bahan yang menjadikan bolu kukus empuk yaitu gula, lemak dan soda kue (Andriani, 2012).

Bolu kukus merupakan produk yang dihasilkan dari tepung terigu atau jenis tepung lain dengan penambahan bahan lain untuk menambah zat gizi yang diproses dengan pengukusan (Widayati dan Darmayanti dalam (Prastika, 2012). Kualitas bolu kukus ditentukan dari rasa, tekstur, aroma dan tingkat pengembangan. Tingkat pengembangan adalah perbandingan tinggi kue bolu kukus dengan tinggi adonan. Faktor yang mempengaruhi tingkat pengembangan antara lain putih telur, soda kue atau 
pengembang kue dan protein yaitu gluten (Putri dalam (Hartandria, 2014)

Bentuk bulat dan merekah 3 bagian pada permukaan bolu kukus dipengaruhi oleh penggunaan bahan seperti telur yang dapat membentuk struktur dari bolu kukus, sehingga menghasilkan bentuk bolu kukus yang bulat (Sari, 2015).

\section{MATODE PENELITIAN Alat dan Bahan}

Alat - alat yang digunakan yaitu: baskom, sendok, mixer, cetakan bolu kukus, dandang (alat pengukus), kompor, gilingan, saringan, timbangan analitik, labu kjeldahl, labu takar, erlenmeyer, tabung reaksi, pipet tetes, cawan petri, cawan porselen, oven, desikator, tanur. Sementara bahannya: ubi kayu, kacang hijau, gula pasir, soda kue, pelembut (SP), telur, vanili bubuk, aquades, bolu kukus, kertas saring, selenium, $7 \mathrm{~g} \mathrm{~K}_{2} \mathrm{SO}_{4}, 0,8$ $\mathrm{g} \mathrm{CuSO}_{4}, 12 \mathrm{~mL} \mathrm{H}_{2} \mathrm{SO}_{4}$ pekat, $30 \mathrm{~mL} \mathrm{H}_{3} \mathrm{BO}_{3} 1 \%, 50$ $\mathrm{mL} \mathrm{NaOH} \mathrm{40 \% ,} \mathrm{larutan} \mathrm{indikator,} \mathrm{HCl} \mathrm{0,1} \mathrm{M} \mathrm{dan}$ kloroform.

\section{Uji Organoleptik}

Uji organoleptik dilakukan untuk mengetahui tingkat kesukaan panelis terhadap produk. Pada pengujian melibatkan 25 orang panelis yang memberikan penilaiannya berdasarkan tingkat kesukaannya terhadap produk meliputi warna, aroma, tekstur dan rasa. Pengujian yang dilakukan adalah menggunakan metode hedonik (uji kesukaan) dengan skala penilaian 1 - 5 yaitu (1) sangat tidak suka, (2) tidak suka, (3) agak suka, (4) suka, (5) sangat suka.

\section{Analisis Kadar Protein (AOAC dalam Hermiastuti, 2013)}

Timbang $1 \mathrm{~g}$ bolu kukus, kemudian dihaluskan. sampel halus dimasukkan ke dalam labu Kjeldahl. Kemudian ditambahkan $7 \mathrm{~g} \mathrm{~K}_{2} \mathrm{SO}_{4}, 0,8 \mathrm{~g}$ $\mathrm{CuSO}_{4}$ dan $12 \mathrm{~mL} \mathrm{H}_{2} \mathrm{SO}_{4}$ pekat ke dalam labu. Semua bahan yang ada di dalam labu kjeldahl dipanaskan dalam lemari asap selama 60 menit, kemudian dinginkan selama 10 - 20 menit. Setelah dingin tambahkan aquades hingga volume total 80 mL. Tambahkan $\mathrm{NaOH} 40 \%$ sebanyak $50 \mathrm{~mL}$, kemudian lakukan distilasi. Distilat yang diperoleh ditampung dalam erlenmeyer yang berisi $30 \mathrm{~mL}$ larutan $\mathrm{H}_{3} \mathrm{BO}_{3} \quad 1 \%$ yang telah diberi indikator campuran. Distilasi dilakukan hingga distilat yang diperoleh sebanyak $150 \mathrm{~mL}$. Kemudian distilat yang diperoleh dititrasi dengan larutan standar $\mathrm{HCl} \mathrm{0,1} \mathrm{M,}$ dibuat blanko, didestruksi, distilasi dan titrasi seperti pada sampel.

\section{Analisis Kadar Lemak (Rakhmah, 2012)}

Timbang $1 \mathrm{~g}$ bolu kukus, dimasukkan dalam tabung reaksi dan tambahkan kloroform hingga terendam. Tutup rapat, kocok dan biarkan semalam, lalu himpitkan dengan tanda skala $10 \mathrm{~mL}$ dengan pelarut lemak. Setelah itu, kocok hingga homogen kemudian saring dalam tabung reaksi. Kemudian pipet $5 \mathrm{~mL}$ ke dalam porselen yang telah diketahui beratnya, dioven dengan suhu $100{ }^{\circ} \mathrm{C}$ selama 3 jam. dimasukkan ke dalam desikator selama 30 menit, kemudian timbang.

\section{Analisis Kadar Air (Chairunisa, 2013)}

Panaskan cawan porselen beserta tutupnya dalam oven pada suhu $\pm 130{ }^{\circ} \mathrm{C}$ selama 15 menit. Kemudian dinginkan dalam desikator selama 20 30 menit dan timbang. Lalu masukkan bolu kukus 5 g ke dalam cawan porselen kemudian timbang. Panaskan pada suhu $\pm 130{ }^{\circ} \mathrm{C}$ selama 30 menit. Kemudian tutup cawan porselen, dinginkan dalam desikator selama $20-30$ menit lalu timbang. Lakukan ulangan $2-3$ kali hingga diperoleh bobot yang tetap.

\section{Analisis Kadar Abu (Rakhmah, 2012)}

cawan porselen dibakar dalam tanur kemudian didinginkan selama $3-5$ menit lalu timbang. Timbang $2 \mathrm{~g}$ sampel yang sudah dihomogenkan ke dalam cawan porselen, lalu masukkan cawan tersebut ke dalam tanur dan bakar sampai didapatkan abu hingga beratnya tetap. Bahan didinginkan kemudian ditimbang.

\section{Analisis Kadar Karbohidrat (Rakhmah, 2012)}

Kandungan karbohidrat dihitung dengan cara menghitung selisih antara jumlah kandungan air, protein, lemak dan abu. Adapun rumus sebagai berikut:

$$
\begin{aligned}
\% \text { Karbohidrat } & =\mathbf{1 0 0} \%-\%(\text { protein }+ \text { lemak } \\
& + \text { abu }+ \text { air })
\end{aligned}
$$

\section{Rancangan Percobaan}

Percobaan menggunakan rancangan acak lengkap dengan 1 faktor pengaruh yaitu jumlah penambahan tepung kacang hijau yang diberikan pada bolu kukus berbahan dasar tepung ubi kayu. Hasil dari penelitian dianalisa dengan uji ANOVA dan uji Duncan pada 6 unit percobaan. Adapun jenis perlakuan tepung yaitu :

\begin{tabular}{lcc}
\hline Kode & Ubi Kayu (g) & $\begin{array}{l}\text { Kacang Hijau } \\
(\text { g) }\end{array}$ \\
\hline A1 & 50 & 75 \\
A2 & 50 & 50 \\
A3 & 50 & 25 \\
\hline
\end{tabular}

\section{HASIL DAN PEMBAHASAN}

Uji organoleptik yang dilakukan adalah uji hedonik (kesukaan) pada bolu kukus dengan bahan yang digunakan adalah tepung kacang hijau dan 
tepung ubi kayu. Pengujian dikakukan untuk mengetahui tingkat kesukaan pada panelis terhadap produk bolu kukus yang meliputi warna, aroma, tekstur dan rasa. Pengujian warna digunakan dalam pengujian organoleptik, karena warna mempunyai peranan penting terhadap tingkat penerimaan produk secara visual. Penentuan mutu suatu bahan pangan pada umunya tergantung pada warna karena warna tampil lebih dahulu (Winarno, 2002).

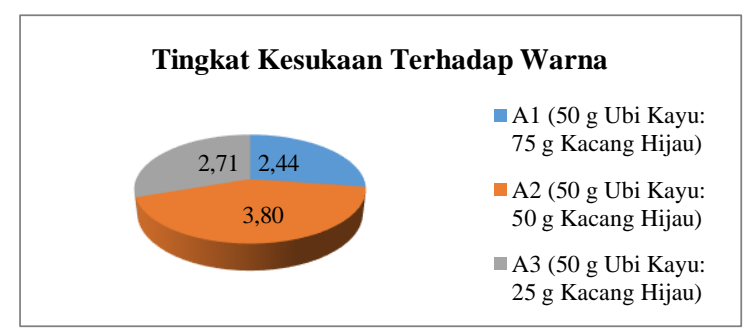

Gambar 1. Organoleptik Warna Bolu Kukus

Hasil analisa sidik ragam, karakteristik warna bolu kukus memberikan pengaruh berbeda nyata pada taraf $\alpha=5 \%$. Nilai F hitung $(74,27)$ lebih besar dari nilai $\mathrm{F}$ tabel $(2,73)$ dan nilai $\mathrm{P}$-value $(0,00)$ lebih kecil daripada nilai $\alpha(0,05)$. Hasil uji Duncan warna bolu kukus dapat dilihat pada Tabel 1

Tabel 1. Hasil Uji Duncan Warna Bolu Kukus

\begin{tabular}{clllll}
\hline Perlakuan & \multicolumn{5}{c}{ Warna } \\
\hline A1 & 2,44 & $\pm 0,42$ & $\mathrm{a}$ & & \\
$\mathrm{A} 3$ & 2,71 & $\pm 0,45$ & & $\mathrm{~b}$ & \\
$\mathrm{~A} 2$ & 3,80 & $\pm 0,32$ & & & $\mathrm{c}$ \\
\hline
\end{tabular}

Standar deviasi warna pada produk bolu kukus berkisar antara 0,32 sampai 0,45. Standar deviasi adalah nilai yang digunakan untuk menentukan bagaimana sebaran data dalam sampel dan seberapa dekat titik data mendekati rata-rata nilai sampel. Sebuah standar deviasi dari kumpulan data yang sama dengan nol menunjukkan bahwa nilai-nilai dalam himpunan tersebut adalah sama (Rohana, 2016). Pengujian organoleptik terhadap warna bolu kukus berkisar antara 2,44 sampai 3,80. Warna produk bolu kukus yang agak disukai oleh panelis yaitu pada perlakuan A2 mencapai rata-rata 3,80 dengan warna yang agak cerah. Warna pada perlakuan A2 lebih bagus dibandingkan dengan warna A1 yang memiliki warna gelap karena adanya pigmen dari kacang hijau dan A3 dengan warna pucat. Hal ini dikarenakan kandungan amilosa yang terdapat pada kacang hijau. Perbandingan warna antara ketiga sampel tersebut dapat dilihat pada Gambar 2.

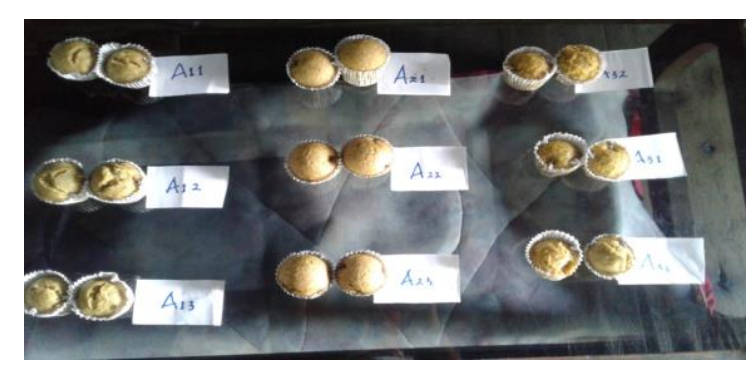

Gambar 2. Warna Bolu Kukusa

Kandungan karbohidrat pada kacang hijau mencapai 72,86\% (Retnaningsih dalam Nisa, 2015). Pati dalam kacang hijau terdiri dari amilosa 28,8\% dan amilopektin sebesar $71,2 \%$. Kandungan amilosa berkolerasi negatif dengan warna dan kilap, semakin tinggi kandungan amilosanya maka warna kurang menarik dan kurang mengkilap (Haryadi, 2006). Menurut Winarno dalam Vyatri, 2015), ada 5 penyebab suatu bahan berwarna yaitu akibat pigmen, reaksi karamelisasi, reaksi maillard, reaksi oksidasi dan pewarna aditif. Warna gelap pada produk makanan disebabkan oleh antosianin yang merupakan sumber pigmen hijau pada kacang hijau.

\section{Aroma}

Aroma menentukan kelezatan bahan makanan. Flavor dari bahan pangan sesungguhnya terdiri dari tiga komponen yaitu bau, rasa dan rangsangan mulut. Bau yang dihasilkan dari makanan banyak menentukan kelezatan bahan pangan tersebut.

\section{Tingkat Kesukaan Terhadap Aroma}

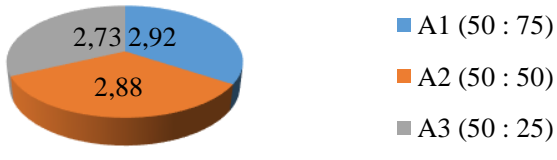

Gambar 3. Organoleptik Aroma Bolu Kukus

Berdasarkan hasil analisa sidik ragam terhadap karakteristik aroma bolu kukus didapatkan bahwa tidak terdapat perbedaan nyata, karena nilai F hitung $(0,342)$ lebih kecil daripada F tabel $(2,73)$ dan nilai P-value $(0,72)$ lebih besar dari nilai $\alpha(0,05)$ sehingga tidak dilakukan uji lanjut. Pengujian dilakukan dengan tujuan untuk mengetahui tingkat respon dari panelis mengenai kesukaannya terhadap formulasi tepung kacang hijau dan tepung ubi kayu pada masing-masing perlakuan.

Tabel 2. Hasil Uji Anova Aroma

\begin{tabular}{crrr}
\hline Perlakuan & \multicolumn{3}{c}{ Aroma } \\
\hline A3 & 2,73 & $\pm 0,62$ & $\mathrm{a}$ \\
A2 & 2,88 & $\pm 0,49$ & $\mathrm{a}$ \\
A1 & 2,92 & $\pm 0,49$ & $\mathrm{a}$ \\
\hline
\end{tabular}


Standar deviasi aroma bolu kukus adalah 0,49 - 0,62. Hasil uji organoleptik terhadap aroma pada Tabel 3. menunjukkan bahwa bolu kukus yang diperoleh dari 3 perlakuan memberikan aroma yang hampir sama yaitu tidak disukai oleh panelis dengan rata-rata berkisar antara 2,73 sampai 2,92. Aroma pada ketiga perlakuan tersebut didominasi oleh aroma dari kacang hijau. Hal ini disebabkan adanya aroma yang khas dari penggunaan tepung kacang hijau dan adanya senyawa-senyawa volatile pada saat proses pengukusan berlangsung. Seperti yang dikatakan oleh Moehyi dalam Nugrahani, (2014), bahwa timbulnya aroma pada makanan disebabkan oleh senyawa volatile. Aroma yang dikeluarkan setiap makanan berbeda-beda. Senyawa volatile yang dimaksud dalam penelitian ini berasal dari penambahan vanlili. Menurut Leong dan Derbesy dalam (Melawati, 2006) menyatakan bahwa flavor vanili mengandung lebih dari 250 senyawa volatile dan kebanyakan dari senyawa tersebut berperan dalam sifat organoleptik secara keseluruhan. Senyawa yang paling penting adalah vanillin dan asam benzoat.

\section{Tekstur}

Tektur memiliki pengaruh penting terhadap produk bolu kukus misalnya dari tingkat kelembutan, keempukan dan kekerasan. Panelis cenderung lebih menyukai tekstur yang lembut, empuk dan tidak keras. Sebaliknya, panelis akan memberi skor yang lebih rendah terhadap bolu kukus yang teksturnya kasar dan keras (Kartika dalam Rakhmah, 2012)). Standar deviasi tekstur pada bolu kukus yaitu 0,39 sampai dengan 0,45. Hasil penilaian panelis pada Tabel 3. menunjukkan bahwa bolu kukus yang diperoleh dari 3 perlakuan memberikan tekstur sangat tidak suka sampai agak suka. Hasil nilai rata-rata penilaian dari 25 orang panelis tidak terlatih memberikan skor terhadap bolu kukus yaitu 1,80 - 3,67 (sangat tidak suka - agak suka).

\section{Tingkat Kesukaan Terhadap Tekstur}

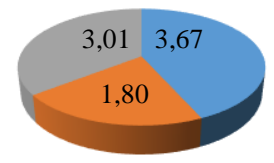

$$
\begin{aligned}
& =\mathrm{A} 1(50: 75) \\
& -\mathrm{A} 2(50: 50) \\
& -\mathrm{A} 3(50: 25)
\end{aligned}
$$

\section{Gambar 4. Organolepik Tekstur Bolu Kukus}

Berdasarkan hasil analisa sidik ragam terhadap karakteristik tekstur pada bolu kukus memberikan adanya perbedaan yang signifikan (berbeda nyata) pada taraf $\alpha=5 \%$, hal ini dikarenakan nilai F hitung $(22,62)$ lebih besar dari F tabel $(2,73)$ dan nilai P-value $(0,001)$ lebih kecil dari nilai $\alpha(0,05)$. Hasil uji Duncan tekstur bolu kukus dapat dilihat pada Tabel 3. Hasil uji organoleptik terhadap tekstur menunjukkan tekstur yang paling disukai oleh panelis adalah bolu kukus pada perlakuan A1 dengan skor 3,67. Perlakuan yang paling tidak disukai oleh panelis adalah tekstur bolu kukus pada perlakuan A2 dengan skor 1,80 karena memiliki tekstur yang agak keras dan tidak mekar seperti bolu kukus biasanya. Tekstur bolu kukus pada perlakuan A3 lebih agak lembut dari perlakuan A2, namun tidak mekar seperti perlakuan A1 memiliki skor 3,01 (agak suka).

Tabel 3. Hasil Uji Duncan Tekstur

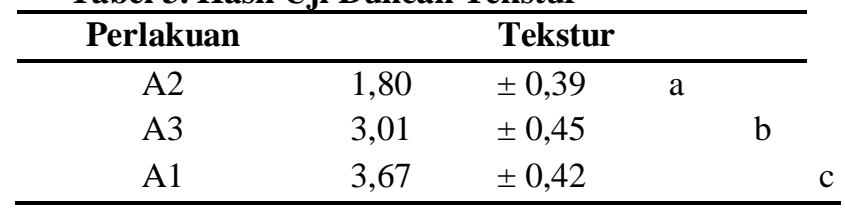

Panelis memberikan skor yang berbedabeda terhadap tekstur bolu kukus yang dihasilkan disebabkan oleh penggunaan tepung ubi kayu dan tepung kacang hijau yang berbeda-beda pada setiap perlakuan serta kandungan yang dimiliki oleh masing-masing bahan seperti karbohidrat dan protein. Hal ini sesuai dengan pernyataan Fellow dalam Mayasari (2015) tekstur makanan ditentukan oleh kadar air, kandungan lemak, jumlah karbohidrat (selulosa, pati dan pektin) serta kandungan proteinnya. Pada pembuatan bolu kukus, tepung yang digunakan adalah tepung dengan kandungan amilopektin tinggi dan amilosa yang rendah agar tekstur bolu kukus menjadi mengembang (Wirakartakusumah dkk dalam Kadarwati, 2015) Kandungan amilosa dan amilopektin yang terdapat pada ubi kayu yaitu $17 \%$ dan 83\% (Wardani, 2011), sedangkan kandungan amilosa dan amilopektin yang terdapat pada kacang hijau sebesar 28,8\% dan 71,2\% (Retnaningsih dalam (Nisa, 2015) Hal ini sesuai dengan hasil pengujian pada bolu kukus perlakuan A1 yang memiliki kandungan amilosa dan amilopektin tinggi dengan karakteristik bolu kukus yang halus, lembut dan mengembang.

\section{Rasa}

Rasa adalah faktor berikutnya yang dinilai panelis setelah tekstur, warna dan aroma. Rasa timbul akibat adanya rangsangan kimiawi yang dapat diterima oleh indra pencicip atau lidah. Rasa adalah faktor yang mempengaruhi penerimaan produk pangan (Rampengan, 1985) 


\section{Tingkat Kesukaan Terhadap Rasa}

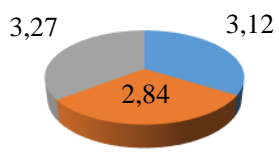

- A1 (50:75)

A2 $(50: 50)$

A3 $(50: 25)$

\section{Gambar 5. Organoleptik Rasa}

Berdasarkan hasil analisa sidik ragam terhadap karakteristik rasa pada bolu kukus tidak memberikan perbedaan yang signifikan (tidak berbeda nyata), hal ini dikarenakan nilai $\mathrm{F}$ hitung $(5,95)$ lebih besar dari $F$ tabel $(2,73)$ dan nilai Pvalue $(0,004)$ lebih kecil dari nilai $\alpha(0,05)$ sehingga dilanjutkan uji Duncan.

Tabel 4. Hasil Uji Duncan Rasa

\begin{tabular}{crrrr}
\hline Perlakuan & \multicolumn{5}{c}{ Rasa } & \\
\hline A2 & 2,84 & $\pm 0,41$ & $\mathrm{a}$ & \\
A1 & 3,12 & $\pm 0,34$ & & $\mathrm{~b}$ \\
A3 & 3,27 & $\pm 0,55$ & & $\mathrm{~b}$ \\
\hline
\end{tabular}

Tingkat rasa produk bolu kukus yang dihasilkan dipengaruhi oleh penggunaan tepung ubi kayu dan tepung kacang hijau ditambah dengan bahan tambahan seperti penggunaan gula, telur, vanili dalam komposisi bolu kukus, selain itu proses pengolahan juga sangat berperan penting seperti pada proses pencampuran (mixing) dan lama pengukusan. Hasil uji organoleptik terhadap rasa bertujuan untuk mengetahui tingkat respon dari panelis mengenai kesukaannya terhadap bolu kukus yang dihasilkan pada masing-masing perlakuan. Standar deviasi pada bolu kukus terhadap rasa berkisar antara 0,34 sampai dengan 0,55. Hasil nilai rata-rata penilaian dari 25 orang panelis tidak terlatih dengan menggunakan metode hedonik yang selanjutnya diolah berdasarkan data yang diperoleh tersebut. Hasil penilaian panelis pada Tabel 4.4 menunjukkan bahwa bolu kukus yang diperoleh dari 3 perlakuan memberikan rasa agak suka, yaitu pada perlakuan A2 dengan rasa yang manis namun tidak gurih dengan skor penilaian sebesar 2,84, perlakuan A1 memiliki rasa yang kurang manis karena persentase dari jumlah penggunaan tepung yang lebih banyak sebesar 3,12 dan A3 memiliki rasa yang manis dan gurih dengan skor penilaian sebesar 3,31. Pada perlakuan A2 memiliki tingkat perbedaan rasa yang disukai oleh panelis dengan perlakuan A1 dan A3. Hal ini disebabkan kandungan pati yang terdapat pada ubi kayu. Menurut Sarwono dalam Yuliyanti, 2016), pati yang telah mengalami proses pemasakan berubah menjadi maltosa yang dapat menyebabkan rasa manis. Rasa sangat berhubungan dengan aroma, karena keduanya merupakan komponen flavor. Senyawa flavor pada produk dapat memberikan rangsangan pada indra penerima. Rasa dipengaruhi oleh beberapa faktor yaitu senyawa kimia, suhu, konsentrasi dan interaksi dengan komponen rasa yang lain (Dwi, 2010)

\section{Uji Proksimat}

Kandungan gizi suatu produk makanan merupakan faktor yang sangat rentan terhadap perubahan perlakuan sebelumnya, selama dan sesudah proses pengolahan. Umumnya selama proses pengolahan terjadi kerusakan gizi secara bertahap pada bahan pangan, misalnya kandungan protein mengalami proses kerusakan atau denaturasi. Tetapi dengan adanya proses pengolahan dapat meningkatkan aroma dan flavor suatu produk makanan (Rakhmah, 2012). Analisis proksimat dilakukan untuk mengetahui kandungan gizi suatu bahan pangan atau produk makanan, seperti kadar protein, lemak dan karbohidrat. Informasi kandungan gizi suatu produk sangat penting untuk mengetahui jumlah energi yang terdapat pada produk seperti yang dapat dilihat pada Tabel 5 .

\section{Tabel 5. Hasil Uji Proksimat}

\begin{tabular}{|c|c|c|c|c|}
\hline \multirow{2}{*}{$\begin{array}{c}\text { Uji } \\
\text { Proksimat }\end{array}$} & \multicolumn{3}{|c|}{ Hasil Perlakuan } & \multirow{2}{*}{$\begin{array}{c}* \text { SNI } \\
\text { Kue } \\
\text { Basah }\end{array}$} \\
\hline & A1 & A2 & A3 & \\
\hline Kadar Air \% & 45,88 & 45,21 & 47,38 & $\begin{array}{c}\text { Maks. } \\
40\end{array}$ \\
\hline Kadar Abu \% & 1,19 & 1,07 & 0,82 & $\begin{array}{c}\text { Maks. } \\
3,0\end{array}$ \\
\hline $\begin{array}{l}\text { Kadar Protein } \\
\%\end{array}$ & 5,25 & 4,86 & 4,07 & $\begin{array}{c}\text { Maks. } \\
9^{*}\end{array}$ \\
\hline $\begin{array}{l}\text { Kadar Lemak } \\
\%\end{array}$ & 2,96 & 2,65 & 2,39 & $\begin{array}{c}\text { Maks. } \\
3,0\end{array}$ \\
\hline $\begin{array}{l}\text { Kadar } \\
\text { Karbohidrat } \\
\%\end{array}$ & 44,74 & 46,22 & 45,35 & $\begin{array}{c}\text { Maks. } \\
55^{*}\end{array}$ \\
\hline
\end{tabular}

\section{Analisis Kadar Protein}

Berdasarkan hasil analisis sidik ragam terhadap kadar protein bolu kukus memiliki perbedaan nyata, dimana nilai $\mathrm{F}$ hitung 93,25 lebih besar daripada nilai $F$ tabel 9,55 dan nilai P-value 0,002 lebih kecil daripada nilai $\alpha=0,05$. Standar deviasi pada kadar protein bolu kukus berkisar antara 0,00 sampai 0,15 . Kandungan protein pada ketiga perlakuan memiliki perbedaan nyata berdasarkan hasil uji Duncan. Hal ini berarti terdapat pengaruh penambahan tepung kacang hijau pada produk bolu kukus yang dihasilkan. Produk A1 berbeda nyata dengan produk A2 dan A3. Kandungan protein pada bolu kukus yang dihasilkan pada sampel A3 sebesar 4,07\%, sampel A2 mengandung protein yang lebih tinggi sebesar $4,86 \%$ dan pada sampel A1 mengandung protein tertinggi sebesar $5,25 \%$.

Dalam bolu kukus, protein yang dihasilkan berasal dari penggunaan tepung kacang hijau, telur dan susu. Kandungan protein yang terdapat pada kacang hijau yaitu sebesar 22 g. Tepung ubi kayu 
memiliki kandungan protein namun dalam jumlah yang sedikit. Menurut (Balagopalan, 1988) kandungan protein yang terdapat pada ubi kayu sebesar 1,60 g. Oleh karena itu penambahan tepung kacang hijau dalam pembuatan bolu kukus ini sangat membantu untuk menambah kandungan protein pada bolu kukus tersebut. Menurut (Rukmana, 1997). sebagian besar jenis protein yang terkandung dalam kacang hijau adalah protein globulin. Protein globulin adalah jenis protein yang tidak bersifat larut dalam air dan mudah terkoagulasi oleh panas.

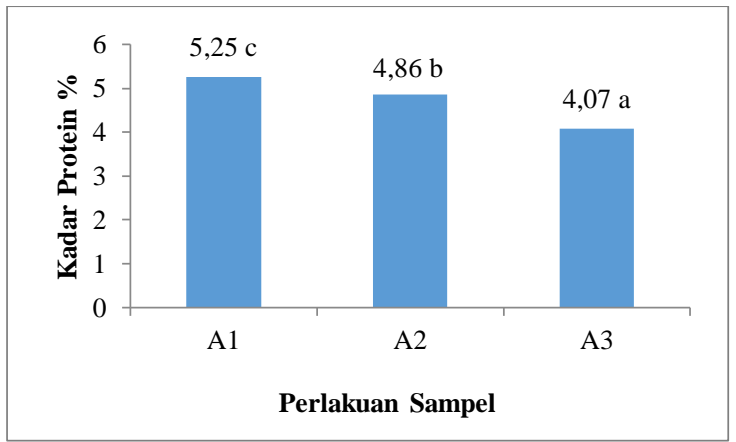

Gambar 6. Kadar Protein Bolu Kukus

\section{Analisis Kadar Lemak}

Pengujian atau analisa kadar lemak yang dilakukan pada penelitian ini bertujuan untuk mengetahui seberapa besar atau seberapa banyak kadungan lemak pada sampel bolu kukus. Sari, Wenggi Sartika.

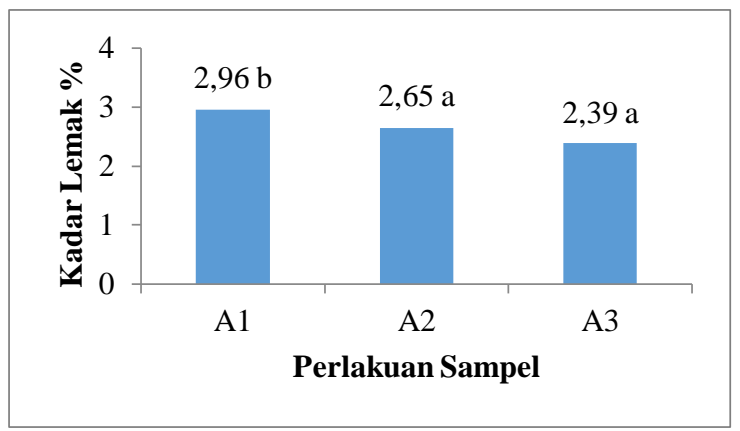

\section{Gambar 7. Kadar Lemak Bolu Kukus}

Kadar lemak pada bolu kukus yang telah diuji pada sampel A1 yaitu sebesar 2,96\%, sampel A2 memiliki kandungan lemak lebih rendah sebesar 2,65\% dan sampel A3 memiliki kandungan lemak paling rendah diantara ketiga perlakuan yaitu sebesar 2,39\%. Diantara ketiga sampel dapat dilihat bahwa sampel A1 memiliki kandungan lemak yang paling tinggi. Seperti halnya karbohidrat, lemak merupakan sumber energi bagi tubuh yang dapat memberikan nilai energi lebih besar daripada karbohidrat dan protein, yaitu 9 kkal per gram (Kurtzweil, 2006). Lemak didapat dari makanan hewani dan nabati antara lain minyak goreng, mentega dan margarin. Lemak berfungsi sebagai sumber citarasa dan memberikan tekstur yang lembut pada produk. Kandungan lemak pada produk bolu kukus yang dihasilkan diperoleh dari penggunaan kuning telur dan susu. Lemak pada produk bolu kukus ini diukur dengan menggunakan metode ekstraksi Soxhlet. Berdasarkan tabel analisis sidik ragam, kandungan lemak yang terdapat pada bolu kukus berbeda nyata (signifikan) dengan nilai F hitung $(18,99)$ lebih besar daripada F tabel $(9,55)$ dan nilai P-value $(0,20)$ lebih kecil dibandingkan dengan nilai $\alpha(0,05)$. Subset pada perlakuan A3 dan A2 hampir sama, sementara dengan perlakuan A1 memiliki perbedaan nyata, dengan standar deviasi berkisar antara 0,09-0,63.

\section{Analisis Kadar Air}

Air merupakan komponen penting dalam bahan makanan karena air dapat mempengaruhi penampakan, tekstur, serta flavor makanan. Kandungan air dalam bahan makanan menentukan acceptability, kesegaran dan daya tahan bahan tersebut (Winarno,2004). Kandungan air suatu bahan pangan sangat penting untuk diketahui utamanya bila bahan pangan tersebut akan diolah menjadi produk yang akan dikonsumsi. Hasil analisa kandungan air dapat menjadi bahan informasi dan acuan dalam melakukan penanganan pasca panen secara tepat sehingga dapat menghasilkan produk olahan yang berkualitas tinggi.

Hasil analisis sidik ragam terhadap kandungan kadar air pada bolu kukus tidak memiliki perbedaan nyata (tidak signifikan) karena niali $\mathrm{F}$ hitung $(1,15)$ lebih kecil dibandingkan dengan nilai F tabel $(9,55)$ serta nilai P-value $(0,43)$ lebih besar daripada nilai $\alpha$ pada taraf $5 \%$. Standar deviasi kadar air pada bolu kukus yaitu 2,39 pada perlakuan A1, 0,41 pada perlakuan A2 dan 0,74 pada perlakuan A3. Dari grafik dapat dlihat bahwa kandungan kadar air pada bolu kukus dengan persentase rata-rata tertinggi terdapat pada perlakuan A3 yaitu 47,38\%, sedangkan hasil rata-rata terendah dapat dilihat pada perlakuan A2 yaitu 45,21\%. Perbedaan kandungan kadar air pada masing-masing sampel dapat disebabkan oleh beberapa faktor seperti komposisi bahan, suhu pengukusan dan ketebalan produk. Perlakuan A3 memiliki kadar air tinggi disebabkan oleh penggunaan tepung ubi kayu dan tepung kacang hijau yang lebih sedikit dibandingkan dengan perlakuan A1 dan A2. Kandungan amilosa dan amilopektin dari bahan utama juga mempengaruhi kadar air pada bolu kukus. Seperti yang dikatakan Akubor dalam (Pradipta, 2015), bahwa sifat dari amilosa yaitu mudah menyerap dan melepas air, sedangkan amilopektin memiliki sifat sulit menyerap air namun air akan tertahan bila sudah terserap. Kandungan amilosa pada perlakuan A3 lebih sedikit dibandingkan dengan perlakuan A1 dan A2. Semakin banyak penggunaan tepung kacang hijau, maka kadar air menjadi rendah. Sedangkan semakin sedikit penggunaan tepung kacang hijau kadar air akan tinggi. 
Perbedaan tersebut dapat dilihat pada adonan A3 yang lebih encer, karena jumlah penambahan bahan lainnya sama pada ketiga perlakuan. Proses pembuatan bolu kukus tersebut adalah dengan pengukusan. Tujuan dilakukan pengukusan yaitu untuk mematangkan produk. Dengan dilakukannya proses pengukusan, secara otomatis kandungan kadar air pada bahan tersebut bertambah karena adanya uap air yang terperangkap didalam bersamaan dengan bolu tersebut. Suatu bahan pangan yang tinggi kadar airnya akan semakin cepat busuk dibandingkan bahan pangan dengan kadar air yang rendah (Winarno, 2004). Kadar air dapat mempengaruhi penurunan mutu makanan secara kimia dan mikrobiologi. Berdasarkan hal tersebut, dapat dilihat bahwa produk yang cepat busuk dari ketiga sampel yaitu pada perlakuan A3.

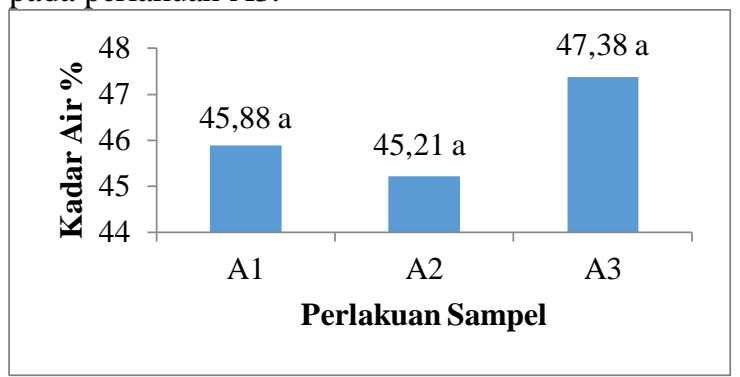

\section{Gambar 8. Kadar Air Bolu Kukus}

\section{Analisis Kadar Abu}

Kandungan abu dan komposisinya bergantung pada macam bahan dan cara pengabuan yang digunakan. Kandungan abu dari suatu bahan menunjukkan kadar mineral dalam bahan tersebut. Semakin besar kadar abu yang diperoleh, maka semakin besar pula kandungan mineral pada bahan tersebut (Muchtadi, 1989). Penentuan kadar abu yang dilakukan pada penelitian ini bertujuan untuk mengetahui jumlah kadungan mineral pada sampel bolu kukus.

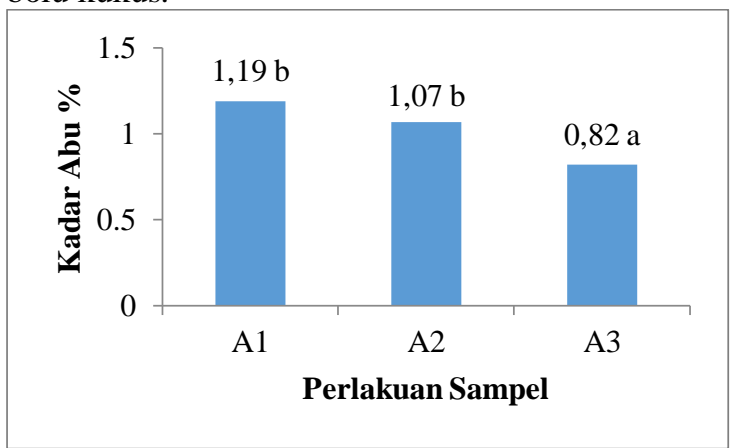

\section{Gambar 9. Kadar Abu Bolu Kukus}

Berdasarkan hasil analisis sidik ragam kadar abu pada bolu kukus memiliki perbedaan nyata (signifikan), karena nilai F hitung $(19,78)$ lebih besar daripada nilai $\mathrm{F}$ tabel $(9,55)$ serta nilai P-value $(0,02)$ lebih kecil darpida nilai $\alpha(0,05)$, perbedaan tersebut terdapat pada perlakuan A3. Standar deviasi terhadap kadar abu bolu kukus sekitar 0,04 - 0,57. Berdasarkan Gambar 9, dapat dilihat bahwa kadar abu bolu kukus dengan persentase rata-rata terendah terdapat pada perlakuan A3 dengan rata-rata $0,82 \%$, perlakuan A2 memiliki rata-rata $1,07 \%$, sedangkan hasil persentase tertinggi terdapat pada perlakuan A1 dengan rata-rata $1,19 \%$. Dalam proses pembakaran atau pengabuan yang dilakukan menyebabkan zat organik dari bolu kukus terbakar, namun zat anorganik atau unsur mineral (kalsium, fosfor dan zat besi) pada bolu kukus tidak ikut terbakar.

Sebagian besar makanan sekitar 96\% terdiri dari bahan organik dan air, sisanya terdiri dari mineral. Unsur mineral juga dikenal sebagai zat anorganik atau kadar abu. Dalam proses pembakaran, bahan-bahan organik terbakar tetapi zat anorganiknya tidak (Fauzi dalam Anshar, 2012). Seperti dalam penelitian ini, produk bolu kukus memiliki kandungan mineral atau zat anorganik yang tidak terbakar pada saat proses pengabuan seperti seng, kalium, magnesium, tembaga, mangan dan thiamin. Unsur-unsur tersebut didapat dari kandungan kacang hijau yang terdapat pada bolu kukus. Hal itulah yang menyebabkan perlakuan pada sampel A1 memiliki kandungan kadar abu tertinggi dibandingkan dengan perlakuan lainnya, karena konsentrasi dari kacang hijau pada perlakuan A1 lebih banyak.

\section{Analisis Kadar Karbohidrat}

Perhitungan kadar karbohidrat yang dilakukan pada penelitian ini bertujuan untuk mengetahui kandungan karbohidrat pada sampel bolu kukus. Berdasarkan hasil analisis sidik ragam, kadar karbohidrat pada bolu kukus tidak signifikan. Nilai F hitung 0,68 lebih kecil daripada nilai $F$ tabel 9,55 dan nilai P-value 0,57 lebih besar daripada nilai $\alpha$ pada taraf 5\%. Standar deviasi dari karbohidrat pada bolu kukus sekitar 0,44 sampai dengan 2,07 dapat dilihat pada Gambar 10. Kadar karbohidrat pada bolu kukus yang dihasilkan pada sampel A1 sebanyak 44,74\%, sampel A2 sebesar 46,22\% dan sampel A3 sebesar 45,35\%. Tingginya kadar karbohidrat pada perlakuan A2 disebabkan karena tingginya kadar karbohidrat yang terdapat pada kacang hijau. Menurut Retnaningsih dalam Nisa dkk (2015), karbohidrat pada kacang hijau sebesar $72,86 \%$ dan menurut Balagopalan et al, (1998) kandungan karbohidrat pada ubi kayu sebesar $84,90 \%$. Dalam pembuatan bolu kukus ini, sumber karbohidrat diperoleh dari bahan-bahan yang berupa tepung ubi kayu, kacang hijau dan gula.

Penurunan kadar karbohidrat pada sampel A1 disebabkan karena adanya aktivitas enzim yang menghidrolisis karbohidrat pada proses perendaman kacang hijau. Hal ini sesuai dengan pernyataan Gsianturi dalam Anggrahini (2007), menyatakan bahwa pada saat proses perendaman, terjadi hidrolisis karbohidrat menjadi senyawa yang lebih 
sederhana, sehingga kadar karbohidratnya berkurang. Karbohidrat didegradasi oleh enzim alpha-amilase dan beta-amilase. Alpha-amilase akan mendegradasi pati menjadi glukosa dan dekstrin, sedangkan beta-amilase memecah pati menjadi maltosa dan dekstrin. Kadar karbohidrat pada bolu kukus yang dihasilkan dipengaruhi oleh proses pengolahan. Ada dua hal penting yang dipertimbangkan mengapa pengolahan pangan perlu dilakukan. Pertama adalah untuk mendapatkan bahan pangan yang aman untuk dimakan sehingga nilai gizi yang dikandung bahan pangan tersebut dapat dimanfaatkan secara maksimal. Kedua adalah agar bahan pangan tersebut dapat diterima, khususnya diterima secara sensori yang meliputi penampakan seperti aroma, rasa, warna dan tekstur (Geri dalam Rakhmah, 2012).

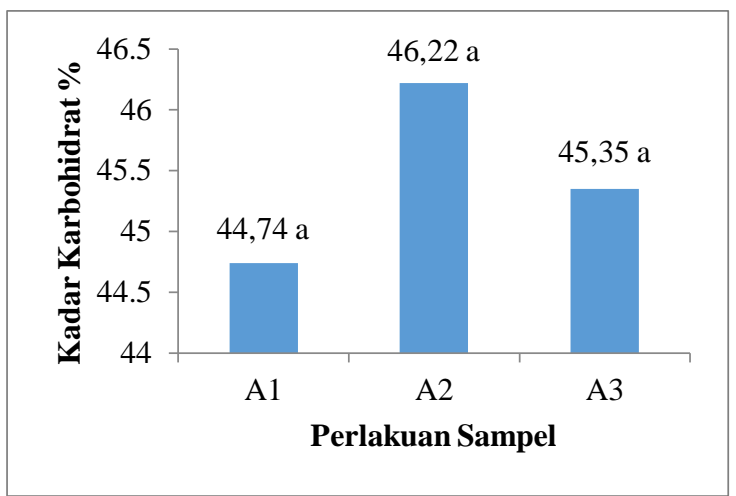

Gambar 10. Kadar Karbohidrat Bolu Kukus

\section{PENUTUP}

\section{Kesimpulan}

Proses pembuatan tepung kacang hijau meliputi proses sortasi, pencucian, perendaman, penirisan, penggilingan dan penjemuran. Proses pembuatan bolu kukus meliputi proses pencampuran bahan (mixing), pencetakan dan pengukusan. Pengaruh tepung ubi kayu mempengaruhi tingkat kesukaan terhadap warna dan rasa dari bolu kukus, sedangkan penambahan tepung kacang hijau berpengaruh terhadap warna, tekstur dan rasa namun tidak mempengaruhi aroma dari bolu kukus. Berdasarkan pengujian proksimat, kandungan kadar abu, kadar protein, kadar lemak dan kadar karbohidrat yang terdapat pada bolu kukus tidak melebihi standar berdasarkan SNI kue basah, sedangkan kadar air dari bolu kukus melebihi standar yang dapat berpengaruh pada daya simpan bolu kukus.

\section{REFERENSI}

Amin, H. (2006). Tinjauan Pustaka Umbi Kayu. Retrieved September 24, 2016, from http://repository.ipb.ac.id/

Anshar, A. (2012). Studi Pembuatan Serbuk Kunyi Putih (kaempferia rotunda L) untuk Minuman Herbal. Makassar. : Program Studi Ilmu dan
Teknologi Pangan.Teknologi Pertanian. Fakultas Pertanian. Universitas Hasanuddin.

Anshari, H. D. (2010). Pemanfaatan Biji Cempedak sebagai Alternatif Pengganti Tepung Terigu dengan Kualitas dan Gizi Tinggi. Malang: Program Kreativitas Mahasiswa. Universitas Negeri Malang.

Balagopalan, C. P. (1988). Cassava Food, Feed and Industry. CRC Press, Boca Raton.: Florida.

Chairunisa. (2013). Uji Kualitas Minyak Goreng pada Pedagang Gorengan di Sekitar Kampus UIN Syarif Hidayatulah Jakarta. Jakarta: Skripsi. UIN Syarif Hidayatullah.

Dahlia, L. (2014). Hidup Sehat Tanpa Gluten. Jakarta: Elex Media Komputindo Gradia Press.

Dwi, S. A. (2010). Analisis Sensori untuk Industri Pangan dan Agro. IPB Press: Bogor.

FAO. (2013). Ketela Pohon. Retrieved September 23, 2016, from wikipedia: http://id.wikipedia.org

Fatsecret. (2017). Kalori dalam Kue Bolu. Retrieved Agustus 08, 2017, from http://fatsecret.co.id.

Hartandria, F. (2014). Uji Kadar Protein pada Pembuatan Bolu Kukus dari Tepung Singkong (Manihot esculenta crantz) dan Penambahan Ekstrak Buah Naga Merah (Hylocereus polyrhizus) dengan Konsentrasi yang Berbeda. Surakarta: Naskah Publikasi Skripsi. Universitas Muhammadiyah.

Haryadi. (2006). Teknologi Pengolahan Beras. Yogyakarta.: Gadjah Mada University Press.

Hermiastuti, M. (2013). Analisis Kadar Protein dan Identifikasi Asam Amino Pada Ikan Patin (Pangasius djambal). Jember: Skripsi. Jurusan Kimia. Fakultas Matematika dan Ilmu Pengetahuan Alam. Universitas Jember.

Kadarwati, M. (2015). Tingkat Pengembangan dan Daya Terima Bolu Kukus Berbahan Dasar Tepung Singkong (Manihot esculenta crantz) yang Disubstitusi Tepung Kacang Hijau (Phaseolus radiatus). Surakarta: Naskah Publikasi Skripsi. Universitas Muhammadiyah Surakarta.

Kadarwati, M. (2015). Tingkat Pengembangan dan Daya Terima Bolu Kukus Berbahan Dasar Tepung Singkong (Manihot esculenta crantz) yang Disubstitusi Tepung Kacang Hijau (Phaseolus radiatus). Surakarta: Naskah Publikasi Skripsi. Universitas Muhammadiyah Surakarta.

Kurtzweil, P. (2006). Daily Valves Encourage Healthy Diet. Retrieved Juli 17, 2017, from http://www.fda.gov

Mayasari, R. (2015). Kajian Karakteristik Biskuit yang Dipengaruhi Perbandingan Tepung Ubi Jalar (Ipomea batatas L.) dan Tepung Kacang Merah (Phaseolus vulgaris L.). Bandung: Program Studi Teknologi Pangan. Fakultas Teknik. Universitas Pasundan. 
Melawati. (2006). Optimasi Proses Maserasi Panili (Vanilla Planifolia A) Hasil Modofikasi Proses Kuring. Bogor: Fakultas Teknologi Pertanian. Institut Pertanian Bogor.

Mustakim, M. (2012). Budidaya Kacang Hijau Secara Intensif. Yogyakarta.: Pustaka Press. .

Nisa, R. U. (2015). Perbandingan Tepung Sukun (Artocarpus communis) dengan Tepung Kacang Hijau (Vigna radiata L.) dan Suhu Pemanggangan Terhadap Karakteristik cookies. Bandung.: Fakultas Keguruan dan Ilmu Pendidikan. Universitas Pasundan.

Nugrahani, A. (2014). Sifat Fisik dan Kesukaan Sensori Kulit Bakpia yang Disubstitusi dengan Tepung Singkong. Surakarta: SkripsProgram Studi Gizi. Fakultas Ilmu Kesehatan. Universitas Muhammadiyah Surakarta.

Pradipta, I. B. (2015). Pengaruh Proporsi Tepung Terigu dan Kacang Hijau serta Substitusi dengan Tepung Bekatul dalam Biskuit. Jurnal Pangan dan Agroindustri.

Prastika, R. (2012). Tingkat Pengembangan dan Daya Terima Bolu Kukus yang Diformulasi Sebagian dengan Tepung Sukun. Artikel Ilmiah. Surakarta. : Fakultas Ilmu Kesehatan. Universitas Muhammadiyah Surakarta. .

Purwanti. (2008). Kandungan dan Khasiat Kacang Hijau. UGM-Press. : Yogyakarta.

Rakhmah, Y. (2012). Studi Pembuatan Bolu Gulung dari Tepung Ubi Jalar (Ipomea batatas L). Makasar: Skripsi. Fakultas Pertanian. Universitas Hasanuddin.

Rampengan, V. P. (1985). Dasar-dasar Pengawasan Mutu Pangan. Ujung Pandang.: Badan Kerjasama Perguruan Tinggi Negeri Indonesia Bagian Timur.
Rohana, R. (2016). Karakteristik Fisiko Kimia dan Organoleptik Minuman Serbuk Instan dari Campuran Sari Buah Pepino (Solanum muricatum, Aiton.) dan Sari Buah Terung Pirus (Cyphomandara betacea, Sent.). Padang: Skripsi. Fakultas Teknologi Pertanian. Universitas Andalas.

Rukmana, R. (1997). Kacang Hijau Budidaya dan Pasca Panen. Yogyakarta.: Kanisius. .

Sari, W. S. (2015). Substitusi Pisang Masak Sehari Terhadap Kualitas Bolu Kukus. Padang. : Skripsi. Fakultas Teknik. Universitas Negeri Padang.

Sindo. (2012). Tepung Singkong Kaya Manfaaat. Retrieved September 24, 2016, from http://www.okefood.com.

Suharno. (1990). Rancang Bangun dan Industri Model Alat Penepung Ketela Pohon. . Yogyakarta.: Laporan Pengabdian pada Masyarakat. Fakultas Teknologi Pertanian. Universitas Gadjah Mada. .

Vyatri, P. B. (2015). Daya Terima Proporsi Kacang Hijau (Phaseolus Radiata L) dan Bekatul (Rice Bran) Terhadap Kandungan Serat Pada Snack Bar. Jurnal Media Gizi Indonesia.

Winarno. (2002). Ilmu Pangan dan Gizi. Jakarta: Gramedia Pustaka Utama.

Yuliyanti, N. D. (2016). Pengaruh Tepung Komposit Jagung (Zea Mays L.) Kacang Hijau dan Ubi Jalar Kuning Terhadap Tingkat Pengembang dan Daya Terima Bolu Kukus. Surakarta: Program Studi Ilmu Gizi. Fakultas Ilmu Kesehatan. Universitas Muhammadiyah Surakarta. 